\title{
Cindy Sherman: uma criptografia corpórea
}

\section{DANUSA DEPES PORTAS}

\section{Resumo}

A proposta desse ensaio convida à reflexão sobre as relações que travamos com o tempo e no tempo que chamamos de nosso. Em função disso, o valor de contemporaneidade nele referido pressupõe não simplesmente o pertencimento a um contexto cronologicamente delimitado, mas sim uma operação de leitura que problematize esse pertencimento, esse contexto e seus limites e referências temporais, valendo-se das séries fotográficas da artista visual Cindy Sherman como intercessor.

Palavras-chave:

Cultura visual, regimes escópicos, dispositivo 


\section{DANUSA DEPES PORTAS}

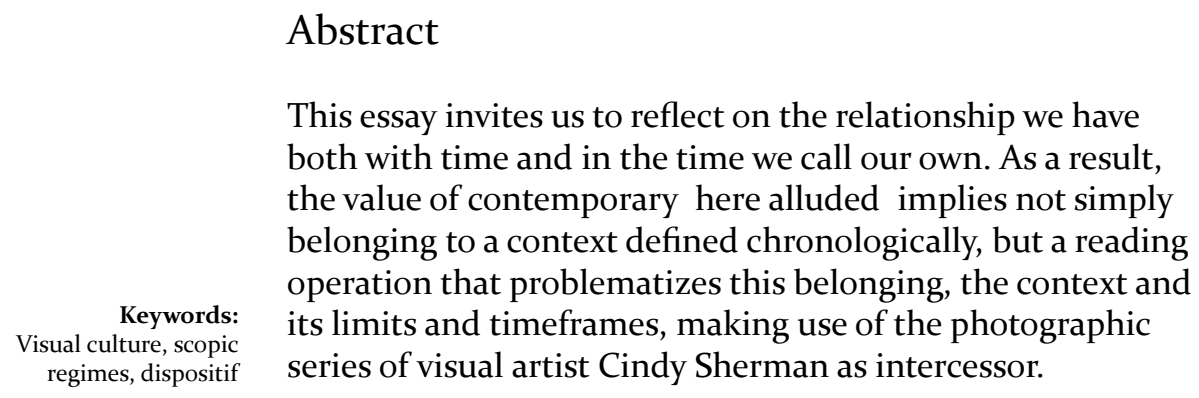

\section{Abstract}

This essay invites us to reflect on the relationship we have both with time and in the time we call our own. As a result, the value of contemporary here alluded implies not simply belonging to a context defined chronologically, but a reading operation that problematizes this belonging, the context and its limits and timeframes, making use of the photographic series of visual artist Cindy Sherman as intercessor. 
L'image n'est pas l'imitation des choses, mais l'intervalle rendu visible, la ligne de fracture entre les choses.

Didi-Huberman

\section{Fricções do sujeito com o Real}

Alain Badiou identificou como a principal característica do século XX a paixão pelo Real. Ele nos diz que ao contrário do século XIX dos projetos e ideais utópicos ou científicos, dos planos para o futuro, o século XX buscou a coisa em si. O momento último e definidor do século XX foi a experiência direta do Real como oposição à realidade social diária. $\mathrm{O}$ Real em sua violência extrema como o preço a ser pago pela retirada das camadas enganadoras da realidade. Paixão que haveria dominado a experiência contemporânea em sua obsessão por desmascarar a aparência. Paixão que se revela em quatro exigências: a revolta crítica, a razão universal, a aposta amorosa e o pensamento emancipador. Paixão, que assim conduzida, culmina no seu oposto aparente, a espetacularização da vida e a existência em estrutura de semblante.

A paixão pelo Real consiste em um paradoxo fundamental: um espetáculo teatral. Se a paixão pelo Real termina no puro semblante do espetacular efeito do Real, então, em exata inversão, a paixão pós-moderna pelo semblante termina numa volta violenta à paixão pelo Real. A verdadeira paixão do século XX por penetrar a Coisa Real através de uma teia de semblantes que constitui a nossa realidade culminou assim na emoção do Real como o "efeito" último, buscado nos efeitos especiais digitais, nos reality shows da TV e na pornografia amadora, até chegar aos snuff movies ${ }^{l}$. Diante dessas evidências, cabe perguntar se existe uma ligação íntima entre a virtualização da realidade e a emergência de uma dor física infinita e ilimitada, muito mais forte que a dor comum? Talvez a imagem sádica definitiva esteja 
também à espera para se tornar realidade: a de uma vítima que não morra de tortura, que possa suportar uma dor infindável sem a opção da fuga para a morte. Será que conseguiremos suplantar os fantasmas de Auschwitz, Guantánamo, Abu Ghraib?

A verdade definitiva do universo desespiritualizado e utilitarista do capitalismo é a desmaterialização da "vida real" em si, que se converte num espetáculo espectral como propõe David Linch em seu filme Mulholland Drive (Cidade dos Sonhos), 2001. Não se trata apenas de Hollywood representar um semblante de vida real esvaziado do peso e da inércia da materialidade na sociedade consumista do capitalismo recente, a "vida social real" adquire de certa forma as características de uma farsa representada, em que nossos vizinhos se comportam "na vida real" como atores no palco - a proposta de Sam Mendes no seu filme American Beauty (Beleza Americana), 1999, é exemplar nesse sentido.

Slavoj Zizek, em Bem-vindo ao deserto do Real (2003), evocando a proposição de Badiou (1986), atenta para uma perspectiva muito interessante, a saber, entender esse fenômeno a partir da noção da "travessia da fantasia" de Jacques Lacan. Na vida diária, estamos imersos na "realidade" (estruturada e suportada pela fantasia) e essa imersão é perturbada por sintomas que atestam o fato de que outro nível reprimido de nossa psique resiste a ela. "Atravessar a fantasia", então, significa identificar-se totalmente com a fantasia. Daí, podemos entender que a fantasia é simultaneamente pacificadora, desarmadora (pois oferece um cenário imaginário que nos dá condição de suportar o abismo do desejo do Outro) e destruidora, inassimilável à nossa realidade. O Real que retorna tem o status de outro semblante: exatamente por ser real, ou seja, em razão de seu caráter traumático e excessivo, não somos capazes de integrá-lo na nossa realidade (no que sentimos como tal), e, portanto, somos forçados a senti-lo como um pesadelo fantástico.

Aqui a lição da psicanálise é: não se deve tomar a realidade por ficção. É preciso ter a capacidade de discernir, naquilo que percebemos como ficção, o núcleo duro do Real que só temos condição de suportar se o transformarmos em ficção. Resumindo, é necessário ter a capacidade de distinguir qual parte da realidade é "transfuncionalizada" pela fantasia, de forma que, apesar de ser parte da realidade, seja percebida num modo ficcional. Muito mais difícil do que denunciar ou desmascarar como ficção (o que parece ser) a realidade é reconhecer a parte da ficção na realidade "real".

Em vista desse preâmbulo um tanto esquemático sobre o traço característico da cultura no século XX, gostaria então de 
convocar o trabalho da artista americana Cindy Sherman que se constitui como um campo fértil para nossos estudos sobre o estatuto das imagens contemporâneas. Ela parece articular todo seu projeto como uma travessia pela fantasia, sob um efeito do irreal a partir da dialética do semblante e do Real.

A imagem é hoje uma ferramenta da desatenção. Quanto mais imagens conseguimos devorar, mais imagens acabamos por esquecer. O resto vai para a vala comum do esquecimento. A artista vem revirar esse cemitério e seus mortos. Restos de corpo em todas as imagens. Em todas as imagens essa impregnação. Cindy Sherman mantêm fixo o olhar no seu tempo, para nele perceber não as luzes, mas os escuros - algo que lhe concerne e não cessa de interpelá-la, algo que, mais que toda luz, dirige-se direta e singularmente a ela. Isso equivale dizer que é também dividindo e interpolando o tempo, que ela está à altura de transformá-lo e de colocá-lo em relação com outros tempos, de nele ler de modo inédito a história, de citá-lo segundo sua necessidade que não provêm de maneira nenhuma do seu arbítrio, mas de uma exigência de resposta. Ela não tem apenas um ângulo de visão sobre o passado, seus olhos são os do anjo da história: onde nós vemos uma cadeia de acontecimentos, ele vê uma catástrofe única, que acumula incansavelmente ruína sobre ruína e as dispersa a nossos pés. (BENJAMIN, 1994, p. 226) Seus olhos de anjo, explode o continuum da história, junta cacos e recolhe estilhaços, numa arqueologia dos afetos ${ }^{2}$ do agora. A imagem é a linha de fratura entre as coisas, o intervalo feito visível.

Do palco resplandecente de um mundo transformado na sociedade do espetáculo, cabe indagar que tipo de seqüência é essa, tão repentina, tão rápida para ir da fascinação à abjeção? Qual é a relação entre o corpo do glamour, o repertório visual da beleza e a câmara dos horrores, câmara do corpo em humilhação, o corpo esfolado em dor? Qual é a natureza da transição, no universo da imagem contemporânea, que parece ir, em um movimento, de tudo-é-representação para o corpo-como-horror? Da proposição segundo a qual o que é real é o simulacro para o colapso do simulacro numa fundição sadeana? Dos Untitled Film Stills (7o's) para o foco no corpo como casa de horrores e museu de cera de Cindy Sherman?

Uma diferença crucial entre o "museu de cera"3 e os Untitled Film Stills diz respeito ao tipo de regime representacional dentro do qual cada um opera. O museu de cera é, entre outras coisas, um produto extremo da estética de representação pós-renascentista como a cópia exata de um referente fisicamente estável, um corpo que aparece diante dela como seu original: 
"reprodução fiel da natureza e respeito pela verdade até os mínimos detalhes, tais são os princípios que orientam a execução de toda obra no museu de cera" (KRAUSS, 1993, p. 217).

Presume-se que o corpo simplesmente exista lá fora no mundo, e então através da habilidade do copista suas formas são fielmente repetidas na cera. Com os Untitled Film Stills essa estrutura de representação é precisamente invertida: o referente nominal existe apenas por meio da representação e dos códigos culturais complexos que ele ativa. Sherman altera sua imagem tão radicalmente de foto para foto que se torna impossível localizar o termo constante que deveria unir a série; o corpo desaparece em suas representações.

Ou antes, o que no senso comum consideramos como sendo o corpo, essa coisa dada, é elaborado durante a série de tal forma que parece ter sido trabalhado pelos códigos e convenções de representação até um ponto de saturação; o corpo é modelado por esses códigos tão completamente quanto a cera é modelada pelos artesãos. Sherman convence o observador de que suas diversas imagens são de fato presenças distintas, mas que "por trás" delas não há qualquer essência de identidade. A noção de identidade - de cada imagem como dando corpo a uma presença distinta torna-se manifestamente um produto de uma manipulação dos complexos códigos sociais de aparência, uma pura superfície.

O que significa dizer que identidade - as profundezas interiores supostamente por trás ou dentro da superfície da aparência - é apenas um efeito de identidade, a transformação semi-alucinante de uma superfície material em uma profundidade imaginária ${ }^{4}$. Altere-se a iluminação, o foco ou granulação da foto e surgirão conseqüências imediatas na noção de "identidade" que está sendo fabricada. Sherman expõe os alicerces materiais da produção de identidade, não apenas os códigos teatrais de vestuário e gesto, mas os códigos fotográficos que vêm juntar-se a eles. Se a granulação na foto faz a figura parecer diferente (distanciada, misteriosa ou desfigurada), isso prova, sem dúvida, que o que havíamos considerado como sendo a fonte da presença à qual respondemos - a figura, o referente, com sua interioridade e profundidade - na realidade emana da materialidade do trabalho de significação, do papel fotográfico e do modo como ele foi processado, do próprio aparato da representação.

A visão "construcionista" do corpo - de que o corpo não é uma constante anatômica, mas uma variável histórica, uma construção social - deveria, por direito, ser serena. Se o corpo consiste apenas em e através de suas representações, por todos os discursos nos quais é evocado (médico, estético, erótico, legal, 
histórico), se ele realmente se evapora na representação, tornando-se sem peso, perdendo suas antigas opacidade e densidade, então em um certo sentido o corpo deveria deixar de ser qualquer tipo de problema, para qualquer pessoa. Inteiramente incluído na esfera do trabalho cultural, aparentemente tornando-se a arena principal da atividade cultural, ele perde finalmente seu caráter primitivo e é completamente assimilado e civilizado. Nesse sentido, a postura construcionista consuma todo o projeto de fazer o corpo desaparecer que caracteriza o Iluminismo. "É por manter o mais distante possível dos olhos, não apenas a dor real, mas tudo o que pode ser ofensivo ou desagradável para as pessoas mais sensíveis, que o refinamento existe"; acrescenta Norman Bryson (1993, p. 218). A partir do século XVIII, práticas nas quais o corpo possuísse qualquer tipo de persistência são caracterizadas como bárbaras e tiradas de vista: execuções não podem mais ser conduzidas diante da multidão e desaparecem por trás dos portões da prisão; animais não devem ser mortos em pátios por açougueiros locais, mas em abatedouros nos arredores da cidade onde ninguém vai; a exposição da carne como algo diretamente cortado de um animal real, com uma cabeça, com órgãos internos, com uma forma de cadáver reconhecível, é repensada de modo que a carne possa deixar de parecer como carne recentemente viva e tornar-se ao invés um produto higiênico, quase industrial, obtido sabe-se lá onde e como; urinar em público é considerado intolerável e os veneráveis pissoirs são removidos; os moribundos, não passando mais seus últimos dias e horas em casa com a família e os amigos, não vão morrer em continuidade com o resto de suas vidas e seu ambiente, mas ao invés são seqüestrados para trás de paredes brancas e monitores de hospital (Ibid., p. 219).

O corpo, então, será feito desaparecer totalmente: dito consistir unicamente em suas representações, será eventualmente visto como nunca tendo existido de outro modo. Para Foucault (1993), a história do corpo é a da sua construção através dos inumeráveis discursos que atuam para produzi-lo "positivamente", isto é, pela primeira vez. É por ser construído pela cultura que o corpo acaba por ser um objeto de investigação histórica, que ele acaba mesmo por existir. Em Foucault o agente de sua sublimação é o discurso-como-visão: o olhar médico que penetra pela barreira da pele até o interior secreto do corpo, investigando cada recesso com clareza panóptica, traçando mapas e gráficos, declarando essa terra descoberta como o último posto avançado do império discursivo. Pode-se traçar um vínculo estreito entre o olhar médico e a Fotografia. É através da fotografia que as úl- 
timas taxonomias serão feitas, das fisionomias criminosas e fora dos padrões, dos grupos étnicos superiores e inferiores, eventualmente de populações inteiras. É o retrato fotográfico que irá, nas mãos das autoridades, esclarecer e registrar mesmo o crime mais obscuro, e finalmente permitir que circule por toda parte $o$ anúncio de que o corpo finalmente foi capturado dentro da rede da representação: é apenas representação, sempre foi.

No entanto, a compreensão construcionista do corpo sempre teve problemas com "dor". O interesse de Wittgenstein (1999) na existência da dor é emblemático do que pode acontecer uma vez que se admita que tudo o que existe, existe no discurso. Quando o significado é identificado com convenção cultural, quando aparece apenas no espaço interativo entre pessoas e não pode mais ser encontrado na cabeça de ninguém, paradoxalmente o corpo retorna com uma urgência que nunca possuíra. A dor marca o limiar em que o contrato de significação e os jogos de linguagem que compõem a realidade social surgem contra algum tipo de limite absoluto: não há nenhum signo que eu possa trocar pela minha dor, não pode ser canalizada em palavras (apenas gritos), ela existe para além dos meus poderes de representá-la diante dos outros. Os outros, por sua vez, que me conhecem apenas através do que posso fazer e ser, dentro do mundo da representação que compartilho com eles, são incapazes de conhecer esta minha dor, que só a mim pertence e não pode ser convertida em qualquer espécie de moeda de significação. No exato momento em que, eventualmente, se estabelece alegação de que o corpo é construído exclusivamente em e como representações, ao invés do corpo tornar-se sem peso, translúcido, completamente iluminado pela luz pura da razão discursiva, ele se estabelece como limite intransponível do discurso.

O que então entra em jogo é o inverso da inclusão do corpo no discurso: a percepção do corpo como simbolicamente recalcitrante e como resistência clandestina da fronteira do império discursivo. O discurso que oficialmente conduz o corpo - abdução tanto quanto inclusão - tropeça, hesita, já que é experiente em correr contra algo que escapa a troca contratual de significantes: uma densidade, uma gravidade, um ficar fora do discurso; um êxtase do corpo como aquele que não pode ser, não será, sublimado no espaço de significação. Daí em diante, o corpo é exatamente o lugar onde algo deixa a ordem da significação - ou não consegue nela entrar. Ao mesmo tempo resíduo e resistência, ele torna-se aquilo que não pode ser simbolizado: o lugar, na verdade, do Real.

Seguindo esse argumento, Norman Bryson nos diz que o corpo é tudo aquilo que não pode ser transformado em repre- 
sentação, e, por essa razão, nunca é reconhecível diretamente: se devêssemos fazer o retrato desse discurso-fora-do-corpo em nossas mentes, não se assemelharia em modo algum com um corpo, já que o corpo-como-semelhança é precisamente aquilo a que não é possível convertê-lo. Mesmo imagens do corpo em abjeção apenas aproximam o que está em jogo aqui, substituindo as meras formas do horrível por aquilo que é essencialmente incomensurável com a forma, é informe. A linguagem apenas pode apontar para esse aspecto do corpo, não pode agarrar sua gordura nem sua umidade, seu excesso para além da significação. Como Lacan descreveu a garganta da paciente de Freud, Irma:

A carne que nunca se vê, o alicerce das coisas, o outro lado da cabeça, do rosto, as glândulas secretoras por excelência, a carne de onde tudo exsuda, bem no coração do mistério, a carne em todo o seu sofrimento, é amorfa, em toda sua forma é, em si, algo que provoca ansiedade. (LACAN apud BRYSON, Cf. KRAUSS, 1993, p. 221)

Tal como a linguagem, a representação visual pode somente encontrar análogos e termos de comparação para esse corpo: é como isso ou aquilo. Nos limites da representação ou atrás dela paira um corpo do qual se saberá a existência apenas porque esses stand-in inadequados, que estão ali somente para marcar um limite ou fronteira para a representação, capazes de conjurar uma penumbra, ou algo que fica além da representatividade. A penumbra indica que o discurso-como-visão não pode detectar muito bem essa região, nem colocá-la em foco. Contudo à medida que o espectador perceba que a visão não consegue confortavelmente esquadrinhar a penumbra (o olhar saindo da imagem, como uma flecha atingindo um escudo), surge uma certa náusea que inconfundivelmente anuncia o advento do Real. Não porque a imagem mostra essa ou aquela coisa horrível - a aparência repugnante do conteúdo da imagem é apenas um obstáculo momentâneo para o discurso, uma vez que logo que os discursos de horror penetrem em seu alvo, eles de uma vez neutralizam-no e absorvem-no de volta ao repertório das convenções. Pelo contrário, o objeto do horror (de prazer) mostrado na foto será sempre inadequado à carga afetiva que ele carrega consigo: o horror nunca está na representação, mas ao seu redor, como um clarão ou um perfume. Na série das Sex Pictures (1992), Sherman consegue jogar exatamente com esse vazio entre o corpo como êxtase-do-discurso e os standin inadequados do corpo no estágio representacional. Daí sua comédia do macabro, seu humor negro: os 
manequins dos estudantes de medicina, as partes do corpo, as máscaras de Halloween e próteses não podem corresponder ao sentimento que induzem, não podem a ele igualar-se. Mas, de um certo modo, o objeto do horror não precisa sequer almejar ser adequado, visto ser apenas um chamariz, não a coisa real, apenas um arauto do Real, um aviso de que o horror está no ar.

Uma vez declarado que o mundo tornou-se representação, e o Real retira-se do sistema, a esfera cultural deve ficar em paz, movendo-se ao redor dos espaços serenos da realidade virtual. Mas a surpreendente conseqüência da conversão da realidade em espetáculo é inversa: uma hesitante sensibilidade ao Real, uma consciência aguçada dos momentos quando a realidade virtual é perturbada, quando avança contra e atinge aquilo que como noção expeliu de seu sistema. Precisamente porque se espera que o sistema de representação discursiva tenha abrangido tudo o que existe, o corpo incluído, as fricções do sujeito com o Real têm uma força que nunca possuíram antes da totalização da representação em "realidade". Como um imã agarrado a uma tela de televisão, as confrontações com o Real fazem a imagem inteira se deformar. Para o sujeito do mundo-como-representação (ou mercadoria/ espetáculo) a abordagem do real induz um tipo especial de medo que pode, historicamente, ser algo novo no mundo: uma ansiedade ou náusea que deriva inesperadamente do próprio sucesso do sistema.

A ação primária do Real nunca é, claro, aparecer: quando assume uma forma (monstro, extraterrestre, vampiro, cadáver), já é de modo seguro dentro do espaço do representacional. A ação do Real é simplesmente que ele se move perto, perto demais. $\mathrm{O}$ núcleo duro daquilo que resiste à simbolização vem em direção ao sujeito como uma curvatura no espaço da própria representação, como um pavor que infiltra a imagem e parece vislumbrá-la por fora e por trás ${ }^{5}$.

Talvez seja isso que subentende o esforço do revival gótico contemporâneo, cujos praticante chave são Cindy Sherman e David Lynch. A estrutura sobre a qual cada um pensa acerca da imagem e do corpo é menos o signo que o sintoma. O sintoma é o que fica permanentemente no limiar da simbolização, mas não pode atravessá-lo; é uma mensagem cifrada prestes a passar para a significação e a cultura, no entanto permanentemente impedida, como um criptograma corpóreo. O que a torna reconhecível (até onde isso é possível) é seu sentimento de terror, enquanto o edifício inteiro da inteligibilidade pessoal e cultural é estremecido por aquilo que excluiu - o objeto-causa do medo e desejo do sujeito. Stricto sensu, o sentimento de terror que surge com 
a proximidade excessiva ou iminência do Real é só o que pode ser sabido aqui, já que aquilo que induz o terror é precisamente inominável. Certamente o seu lugar é o corpo, mas não o corpo que surge em Foucault, produto da disciplina, conhecimento e técnica do Iluminismo. Aquilo que a teoria do corpo disciplinar passa por cima, num silêncio metodológico, é o corpo precisamente como o obstáculo disciplinar, a Coisa densa e desobediente que escapa da absorção no panóptico teatro do poder. Escuro, escondido, eis o preço a ser pago pela ideia do corpo como disciplinado e domesticado; sua monstruosidade é aquela de todas as secreções amorfas que recuam para o sujeito como refugos da arena disciplinar - o que já é falar de sua necessidade para a ordem simbólica.

A estrutura do sintoma é apenas parcialmente compreendida se pensarmos nela como a verdadeira fala do corpo, brotando de dentro dele e batendo na porta da cultura. Ao invés disso, é a massa total de resíduos criados como lixo do teatro do imaginário cultural, onde o sujeito assume e internaliza seu repertório de aparências convencionais e sancionadas. Ele passa a ser com e fora desse teatro de representações. E quanto maior for o escopo e a extensão do teatro imaginário (quanto mais perto este chegar da declaração de que tudo o que existe foi absorvido pela cultura), maior será a ameaça colocada pelo sintoma à estabilidade interna do sujeito. Sua essência é um axioma elementar incapaz de uma maior elaboração: simplesmente que "aconteceu algo de errado com o corpo".

Tanto no trabalho de Lynch quanto no de Sherman o que intensifica o pavor do sintoma é que nada da "realidade" disponível parece forte o suficiente para desviar ou rechaçar a incursão temida do Real. Em uma ordem clássica de representação (como a do museu de cera), baseada nos dois termos original e cópia, a representação do horror - embora assustadora - nunca passava de um fantasma ou um pesadelo temporário, visto que, independentemente de quão ruim o sonho tivesse sido, sempre se podia levantar e mudar da zona de representação perturbadora de volta para o porto seguro de um mundo real e de um estado acordado. Mas no regime visual contemporâneo, construído em torno da ideia do colapso da oposição clássica entre real e cópia e sobre a absorção da realidade no interior da representação, não há espaço fora do teatro da representação para o qual o sujeito possa correr. Uma ordem aparentemente fechada, a representação agora não possui qualquer ponto de saída, nenhuma saída de emergência. Seu espaço é como aquele do bardo tibetano, uma região onde após a morte diz-se que o sujeito assiste à execução 
completa de todas as suas fantasias de desejo e medo, mas de uma posição de total encurralamento e incapacidade de desviar-se do objeto-causa de pavor. Nos Untitled Film Stills tudo o que permanece de uma realidade amplamente engolida dentro da representação são fragmentos narrativos e visuais de antigos gêneros cinematográficos (film noir, Hitchcock, Nouvelle Vague, Neo-realismo, etc). Nenhuma dessas inconsistentes películas tem força para manter cercado o avanço do Real em direção ao sujeito (o mesmo pode ser dito sobre Lynch: as citações do cinema mais antigo - de musicais, road movies, comédias, ficção científica - servem apenas para enfraquecer ainda mais o espaço narrativo, deixando-o impotente diante da usurpação do Real).

Duas imagens de Sherman, uma canção de inocência e uma de experiência, Untitled Film Still \# 48, de 1979, e Untitled \# 250, de 1992. Elas não poderiam ser mais diferentes. Em que ponto Sherman passou para o lado negro? Voltando as páginas das "obras completas", pode-se perceber tardiamente que apesar do otimismo da primeira imagem, sua qualidade alegre de "partida" (pode-se lembrar o título de uma crítica de 1983: "Here's Looking at You, Kid”; Waldemar Januszczak), a estrutura sintomática já está inteiramente no lugar: a primeira proposição, que o real está agora sendo completamente assimilado na representação (nesse caso, atravessando os códigos do cinema); e a segunda, sua conseqüência, que essa mesma absorção esconde em seus limites uma atmosfera de terror, fora da tela e nas bordas da representação, um medo pelo e do corpo no exato momento de sua sublimação ou desaparecimento no teatro representacional.

Na segunda imagem o real move-se muito mais perto, e o corpo de Sherman desaparece fisicamente da cena, sinal de sua pretensão ao equivalente visual do "texto social", o fluxo de imagem. O que ressurge dessa mesma desaparição é tudo acerca do corpo que o fluxo de imagem joga fora a fim de manter as noções do corpo como socializado, limpo, representável: a densidade material do corpo, suas pulsões e impulsos internos, a convulsibilidade de sua dor e prazer, a espessura de seu deleite.

Mas todas essas fotos são apresentadas como simulacros, em certo sentido entrando num emergente e moderno fluxo de imagem, enquanto um evento no tecido do real conduz abruptamente para tudo que excede o repertório aceitável de imagens: assassinato, tortura, estupro, execução, com o estado em suas vestes de pura violência e o sujeito civil tratado como uma espécie de fardo de carne sombriamente desejada. Com Sherman vemos a mesma (ou uma relacionada) cultura. As apostas são mais altas e a representação está no processo de colocar os toques finais em sua colo- 
nização do real. Em suas margens, contemporâneo a esse projeto colonizador e conseqüência dele, está o corpo sintomático de dor e prazer, de deleite. O movimento do ideal para o abjeto é um natural deslizamento na trajetória da carreira de Cindy Sherman.
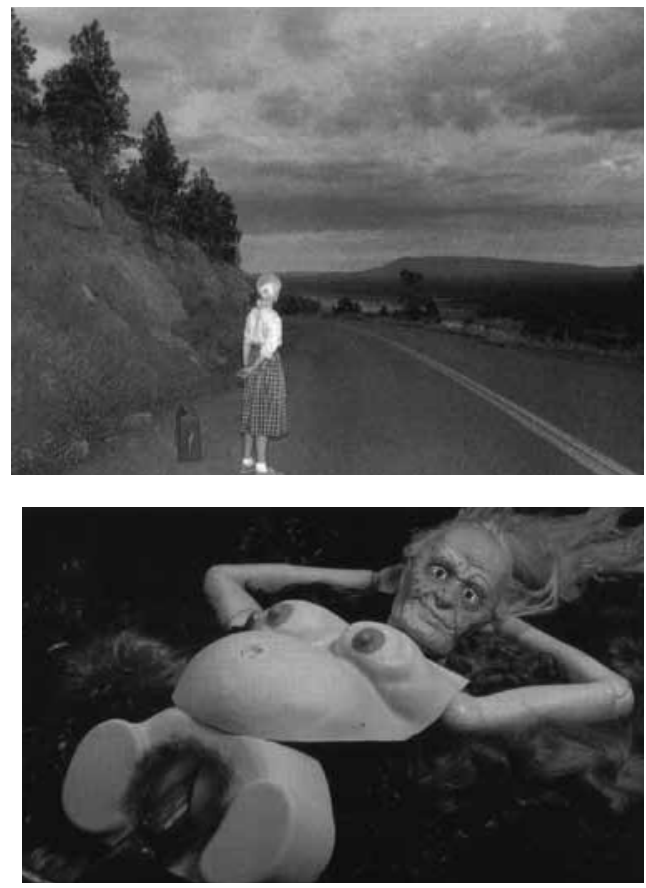

\section{$O$ efeito anel de moebius}

No atual regime de visibilidade, a imagem aparece como meio de exposição daquilo que, no interior do inorgânico, do reificado é capaz de provocar o olhar fascinado. Poucos foram tão longe nesse arriscado jogo de indiferenciação entre publicidade, pornografia, cultura pop. Suas imagens, concatenações de estereótipos, reproduzem objetos que já são reproduções: personagens dos cenários de Hollywood, de filmes de Douglas Sirk, de film noir, da Nouvelle Vague, do snuff movies e da foto publicitária das revistas de luxo. Em seus ensaios fotográficos nos reencontramos constantemente perante soluções formais que são produtos de receitas estandardizadas. Cindy Sherman é uma colecionadora recitando toda uma cultura visual, sua obra constitui um inventário de motivos e procedimentos.

Nas suas séries fotográficas pode-se perceber uma reivindicação contemporânea da circulação de imagens e de media
Figura 1

Untitled Film Still \# 48, 1979, Cindy Sherman

Figura 2

Untitled \# 250, 1992,

Cindy Sherman 
dominado pela dinâmica da cultura da imagem. Suas séries são urdidas de forma a nos mostrar as próprias condições de surgimento e de recepção, um dispositivo de inscrição e escritura que coloca em situação, numa estratégia complexa, fotógrafo e observador. Promovendo deslocamentos e transferências entre fotografia, cinema e arte, Sherman constrói uma metalinguagem com a qual pode então operar em um plano mito-gramático da produção artística, apontando, assim, para um entendimento do termo estética como um modo de articulação entre maneiras de fazer, formas de visibilidade dessas maneiras de fazer e modos de se pensar suas relações.

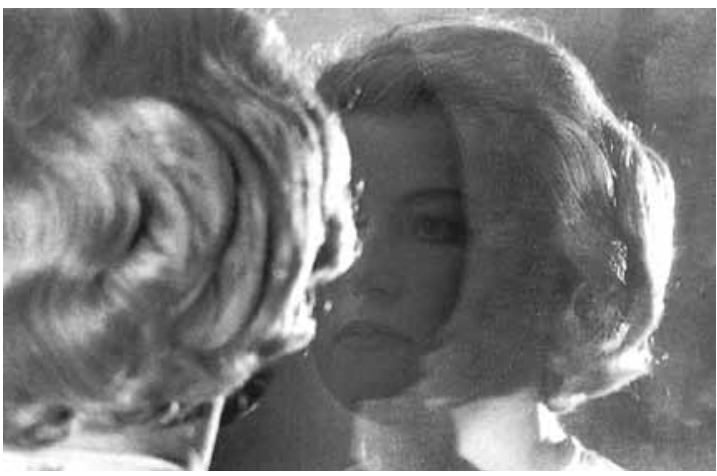

O primeiro grande ensaio fotográfico de Sherman, Untitled Film Stills (1977-1980), já coloca um problema central da imagem clássica, o conceito de identificação, pois detecta a crise da representação nas operações fundadas na figuração, produzindo uma corrosão da figura até transformá-la em superfície, em pura imagerie - lógica que guiará os ensaios subseqüentes: Rear Screen Pictures, Centerfolds, Gleams and reflection, etc.

Os Untitled Film Still são precisamente sobre a transformação de vidas vividas em vidas produzidas mecanicamente, como a indústria dos sonhos produz nada mais do que clichês irresistíveis que introjetam compulsivamente, até o ponto em que não há nenhuma vida que tenha sido previamente empacotada e inscrita, contada, determinada, subsumida. A indústria dos sonhos, mais do que fabricar os sonhos dos consumidores, introduz os sonhos dos produtores em meio às pessoas. A reificação não é nenhuma metáfora: ela faz com que os seres humanos que reproduz se assemelhem às coisas, mesmo onde os seus dentes não representam pasta de dente e suas rugas de preocupação não evocam laxativos.

Quem quer que vá a um filme está apenas esperando pelo dia em que esse feitiço seja quebrado, e talvez, no final das 
contas, apenas essa esperança bem guardada leve as pessoas ao cinema. Mas, uma vez lá, elas obedecem. Elas se incorporam ao que está morto.

Muitas das Cenas de filme sem título, se não a maioria delas, apreendem uma personagem no meio da ação, de modo que, pela imaginação, projetamos na cena uma estrutura narrativa, a própria narrativa, por assim dizer, da qual a cena foi retirada.

Mas, é claro, não há nenhuma narrativa aqui, nenhuma história, tudo já está decidido. A narrativa, o filme que passamos mentalmente, é uma "cena"6, parada e congelada; portanto a temporalidade desdobrada, que pretende ser a prerrogativa do filme sobre a fotografia, é uma falácia. A verdade da temporalidade do filme é a cena. E essa redução pretende contar algo contra o filme e a fotografia. Sendo captada por um clichê, uma cena, cada personagem retratada está decretando uma mimese com a morte; elas são o veículo e a vítima do clichê que exemplificam. Portanto, cada fotografia é a mimese dessa mimese com a morte.

Figuras 4 e 5 Untitled Film Still \# 7, 1978, Cindy Sherman

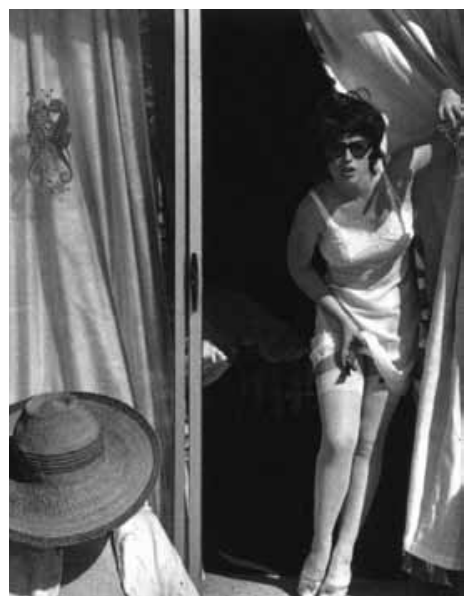

A partir disso, parece necessário inferir (uma inferência exigida, de qualquer modo, pelas últimas obras de Sherman) que a artista não tinha a intenção de que as séries fossem uma posição em favor da tese de que o eu não é nada mais do que um tecido de clichês, nada mais do que um portador de significações culturais. Pelo contrário, essa tese é seu alvo, o que ela pretende estar interrogando e negando. Por todas as suas referências nostálgicas ao passado recente, todo o seu charme, astúcia e conhecimento, há algo de desconcertante e escuro sobre as Cenas de filme. E é no território de sua escuridão que reside sua autoridade enquanto obra. 
Podemos, por hipótese, pensar que as Cenas de filme, de Cindy Sherman, apesar do fato de a artista figurar em todas elas, não são auto-retratos. Ela é sua própria modelo e, como é o caso com todas as modelos, isso não a torna o tema de sua arte. Ela não se rende ao desejo voyeurista que provoca. Ela é o objeto do olhar do observador, mas também o controla, por dirigi-lo como fotógrafa. Como artista, ela está no comando total de suas intenções. Como sua própria modelo, ela abriga clichês intensificados. Entretanto, esse raciocínio me parece enganoso.

Se Sherman tivesse feito apenas uma Cena de filme, seu efeito não seria o ocasionado de fato por essas fotografias - somente o efeito de um ato esperto de personificação. $O$ fato de cada cena/ foto fazer parte de séries indefinidamente longas, cujo poder cumulativo depende de cada momento da série ser só um clichê, é constitutivo para a força de cada retrato. E cada retrato, cada captação de um sujeito por um clichê, é uma captação de Cindy Sherman.

Parte da dificuldade e fascinação de Cenas de filme é que estamos intensamente cientes de que testemunhamos Cindy Sherman em cada um, além das personagens retratadas. Portanto, o que começa como admiração de sua habilidade de personificação e disfarce, por uma aparente mobilidade e identificação de seus aspectos, que lhe permite abordar um grupo de personagens tão divergentes, torna-se cada vez mais uma situação de ansiedade. E aqui começa a importar terrivelmente que se trata de fotografia, e, como tal, permanecerá a indexação casual do retrato ao original a "máscara mortuária" do objeto original. A indexação do retrato ao original é o que transforma o sentido do que quer dizer ser um "modelo" para a pintura e a fotografia. O que existe a mais em cada fotografia, a força expressiva da vulnerabilidade que relaciona a personagem ao clichê e Sherman à personagem, o excedente que deve ser chamado de presença animista do sujeito, sobre e além de sua captação no clichê, volta-se precisamente para o excedente de cada conteúdo explícito, além do artifício, que é uma conseqüência da combinação do olhar mecânico da câmera (cada um indexado por causalidade a Cindy Sherman), e a proliferação de imagens, cada uma delas fazendo parte de uma série indefinidamente longa. Por fim, o que constitui o fato mais perturbador e insólito acerca das séries é que elas não podem ser nada além de auto-retratos. A proliferação de auto-imagens feita por Sherman consegue chegar à sua força persistente, exemplificando o desejo de si em cada uma das formas inadequadas que o negam.

A infinidade viciosa da sujeição pertencente à indústria cultural está recitada e representada nas séries, a fim de reve- 
lar tanto a infinidade viciosa por si mesma, quanto o fato de que em virtude da repetição da repetição, a própria Sherman é aquele limite extremo, o excedente que abre caminho através do olhar estetizante da câmera, o brilho, sedução, e aura de cada clichê. A não ser que essas fotografias fossem auto-retratos, não seria possível abrir caminho.

É fácil ver por que essas fotografias foram apropriadas tão prontamente para metas pós-modernas. Sugerindo que a força das Cenas de filme é um animismo, e identificando esse animismo como momento de excesso ou abertura de caminho além da imagem, está implicado um pathos. Esse pathos deve ser considerado como uma conseqüência da indexação casual da imagem ao fato, chamemos assim, de Sherman por si mesma. Ela só pode aparecer como efeito reflexivo e não como imagem, o efeito de sua reiterada aparição com cada retrato, esse excesso dentro de cada repetição.

Em seus trabalhos dos anos 8o, Sherman procurou reanimar e re-materializar, encontrar representações da vida que resta a ela e a nós, interrogar o que é vivo e o que é morto nela e em nós. Ao procurar representações do que foi ignorado ou considerado indigesto, por obra da indústria cultural, ela se volta inicialmente, sem surpreender, para a fantasia, para a nossa imaginação do que ainda resta além do clichê cultural, deixando a fantasia de uma outra vida se fundir apenas lentamente com a tentativa de imaginar exatamente a vida dizimada.

Sem título, \# 153 me toca como sendo apenas mais uma cena de filme com o contraste da face da morta e a grama perfeitamente verde, lama e sujeira sugerindo que há uma falta terrível aqui - toda a vida está no verde e toda a morte no ser humano. O que torna essa fotografia inquietante é a ausência de horror, a ausência do evento devastador que ocasionou essa conclusão composta, quieta, parada. A quietude composta da cena ecoa o olhar calmo, embelezador, da câmera (ele mesmo um eco quieto da beleza da escultura clássica). Sabemos a resposta para a questão que seria o título do filme, Quem matou a loura?

Compare-se isso com a obra Sem título, \# 177. Envolvê-la também compõe uma narrativa; talvez um filme de terror realista, um filme de impacto. A morte, o estupro, a violação, o terror prestes a acontecer e acontecendo, nada disso está ali; talvez porque, vendo essas coisas, não veríamos o que é preciso, ou porque as vemos com muita freqüência e de um modo equivocado. Em vez disso, temos de encarar a face no canto direito, com o olhar fixo em nós - ou será que ela está observando a própria cena de devastação? -; a face se encontra escurecida por sombras roxas e 
azuladas, um pouco fora de foco; não está claro se essa é a face de uma pessoa viva ou morta, se é a assinatura de Sherman, a aparição fantasmática do corpo violentado.
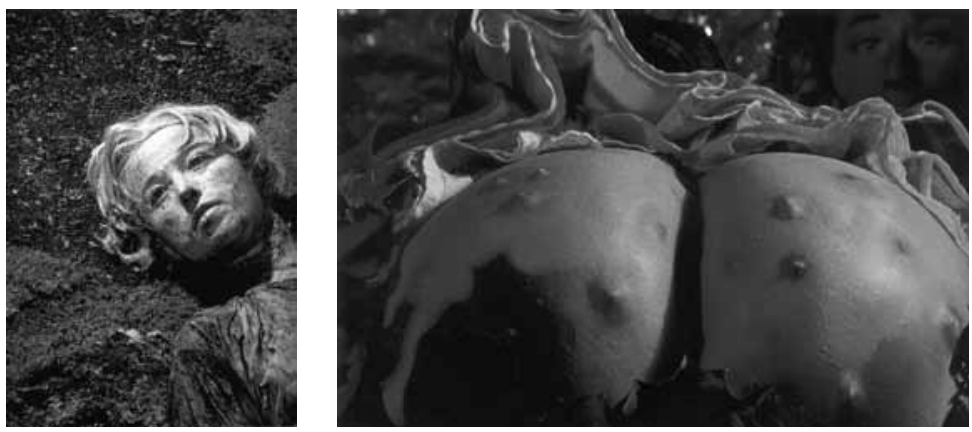

Figura 6 Untitled \#153, 1985, Cindy Sherman

Figura 7 Untitled \#177, 1987, Cindy Sherman
Cada uma dessas fotografias é objeto coercitivo da atenção visual, espetáculos sem receita de cor, fantasia, ansiedade, os quais, em seu momento exuberante, alucinatório, de excesso sensorial e dissonância, conjuram e instituem um animismo resplandecente, mas algo muito distante da face humana ou da figura humana: trata-se de vida fora do lugar, espinhas nítidas, e uma longa língua carnuda que agora suporta toda a carga da afirmação de que a vida vive. No extremo dessas séries, encontram-se as imagens de decadência e as que empurram a questão da vida para o limite de indeterminação entre o orgânico e inorgânico. Talvez o retrato \# 190 seja o mais incisivo deles, já que inevitavelmente nos faz referência às miríades de faces que eram e não eram Cindy Sherman nas Cenas de filme sem título. Qual o significado de uma face humana que pode ser ou tornar-se tão sem face? O que está nos olhando de volta numa face que foi subsumida por um clichê? $\mathrm{O}$ que é uma face humana viva agora? Face a face.

O primeiro aspecto que se nota em Sem título, \# 190, é sua superfície viscosa escura; trata-se de adornos e enfeites visuais que, como o brilho na superfície da própria foto colorida, chamam atenção do nosso olho ingênuo. Como é fácil fazer um truque para que olhemos! Como é casual a nossa compra do espetáculo visual. Mas isso tudo é superfície, e a superfície é bosta. Se olharmos mais demoradamente, trata-se de algo manchado, dentes brancos e língua avermelhada cobertos com excremento, o que pensamos que deve ser excremento, a imagem exata do indigesto, do qual não podemos tirar os olhos. A nossa fascinação inicial se desdobra em desgosto, que fica em suspenso na fascinação. Será que essa face, com seus olhos azuis como os lampejos indeterminados de onde o azul vem, está enterrada na sujeira 
do cólon ou emergindo para fora desta? Talvez se quisesse dizer, sobre essa imagem, que a sua feiúra é demais, é próxima demais do clichê do que é horrível para ser realmente revoltante, e que enfim ela é quase cômica, terror kitsch, uma fonte de riso dificultado e muito presente. Mesmo se isso for verdade, não é igual ao horror cômico dos filmes de terror clássicos, pois, seja vendo a imagem como algo que desgosta de verdade ou como algo que desgosta comicamente, ficamos com uma impressão: a cena do excremento é o hábitat natural à face humana.

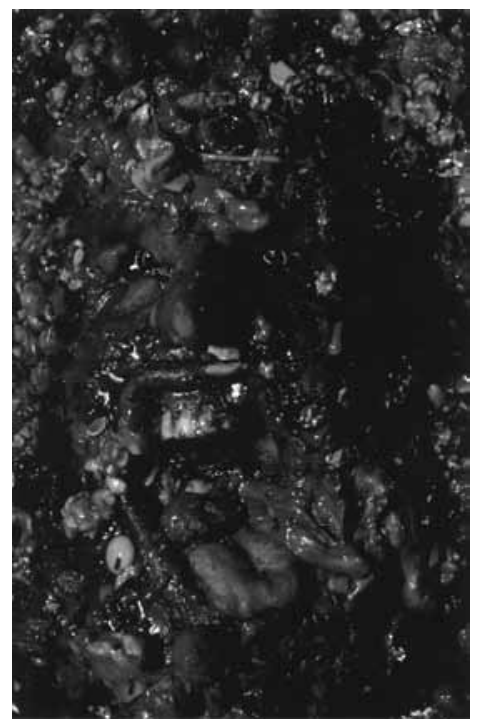

Figura 8

Untitled \#19o, 1989,

Cindy Sherman

Ao sugerir que a cena do excremento é o hábitat natural à face humana, estou querendo despertar interesse pela alegação de que se trata de um estrato de significado, não de um real além do significado, mas de um local de significado, onde este começa. Trata-se do lampejo de luz se tornando o lampejo do olhar, a vida emergindo do lodo e mergulhando nele novamente, no grito de horror, ou agonia, ou desgosto, por meio do qual a natureza revoltante se torna um objeto (ou objeto que estamos olhando), torna-se algo que fica em suspenso, ou oposto a, ou diferente de nós, mas faz parte de nós: afinidade fantasmagórica.

Compare-se essa maneira de pensar sobre e reagir a Sherman com Norman Bryson (1993). Ele argumenta que o corpo é tudo aquilo que não pode ser transformado em representação, e por essa razão nunca é reconhecível diretamente: se devêssemos fazer o retrato desse discurso-fora-do-corpo em nossas mentes, não se assemelharia de modo algum a um corpo, já que o corpo-como- 
-semelhança é precisamente aquilo a que não é possível convertê-lo. Assim como a linguagem, a representação visual só pode encontrar análogos e termos de comparação para esse corpo: é como isso ou aquilo. Nos limites da representação ou atrás dela paira um corpo de que você ficará sabendo apenas por causa desses posicionamentos inadequados, que estão ali simplesmente para marcar um limite ou fronteira da representação, capazes de conjugar uma penumbra, ou algo que fica além da representabilidade. A penumbra indica que o discurso-como-visão não pode detectar muito bem essa região, nem colocá-lo em foco.

Esse discurso repetiria as mesmas suposições sobre o significado que são a causa e raiz da violência do discurso criticada pelas imagens de Sherman? O contraste entre representação e real assume que nós - subjetividade, linguagem, práticas discursivas, enfim, como se queira chamar - somos o local ou origem, ou fonte auto-suficiente de todo significado e sentido, que as nossas capacidades de falar e significar talvez sejam condicionadas por um substrato material, mas não são dependentes desse substrato. Nós impomos significados ao mundo, nós o damos.

Então, quando Bryson sugere que os manequins e as partes do corpo de estudos médicos, assim como as próteses não podem estar à altura do afeto que produzem, não podem igualar esse afeto, podemos muito bem perguntar: de que tipo de falha se trata? O que é fornecer uma representação, uma mimese de dor, ou terror, ou violação? Será que a linguagem chega a "igualar" os afetos que produz? E o riso? Que espécie de equiparação está tendo lugar nesse caso? Será que o desafio dessas imagens não é apenas o fato de o momento de significação ser o momento de excesso, o fato de que a interpretação visual é conservada e completada no modo não-discursivo? Ầ medida que nossos conceitos, e suas distinções (humano/ não-humano, vivo/ morto, irreal/ muito real), caem por terra, só então a cena se torna presente.

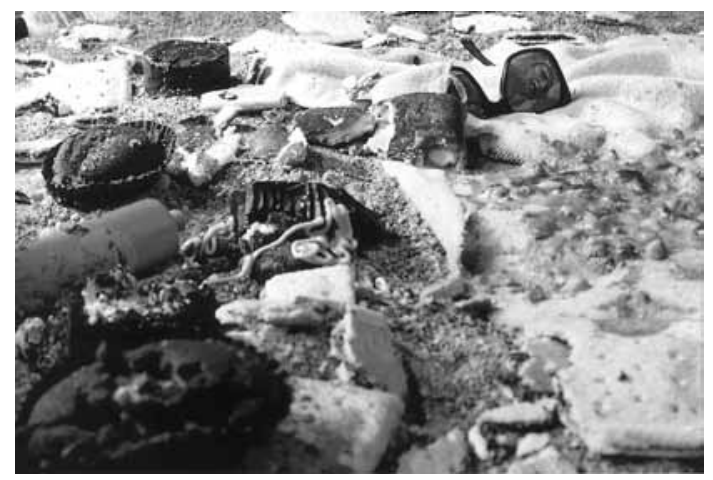


O que Sherman apresenta vai além do regime de representação racionalizada da indústria cultural, além do que é estabelecido como formações de significado e importância. O que re-emerge daquele desaparecimento mesmo (o do próprio corpo de Sherman como sujeito/ objeto) é tudo, sobre o corpo, que a torrente de imagens joga fora a fim de manter as ideias do corpo como socializado, limpo, representável: a densidade material do corpo, suas tendências e pulsões internas, as convulsões de suas dores e prazeres, a espessura de seu deleite. Enquanto espinhas nítidas, língua tosca, sujeira de cólon são substitutos para esse real, e imagens dele, no contexto da obra de Sherman eles não são o que está além da representação, mas sua própria origem contingente. Não só abrem caminho através do conhecimento racionalizado, mas também forçam sobre nós, com insistência aterrorizante ou cômica, uma outra cena de conhecimento: o que não podemos engolir, ingerir, provar, equivale àquilo de que não podemos duvidar. A ilusão de domínio racional, ou o jogo do signo, é minada em uma instância de reviravolta cognitiva obrigatória. O terror é uma das formas de arte que Sherman emprega a fim de permitir a fala dessas outras. Ou, pode-se dizer, Sherman dispõe o terror como um modo ou maneira de abstração (ou revela que o terror foi isso o tempo todo), e assim de desrealizar o dado, removendo o significado determinado e doação objetiva, a fim de lhes fornecer uma insistência ilusória que devolve uma força para originar. As afinidades são indexadas empiricamente e ligadas historicamente - são a conseqüência do mecanismo, da discursividade, do implacável clichê. Sherman oferece um novo material a priori, e desse modo algo que relembra a experiência para além do que a experiência se tornou.

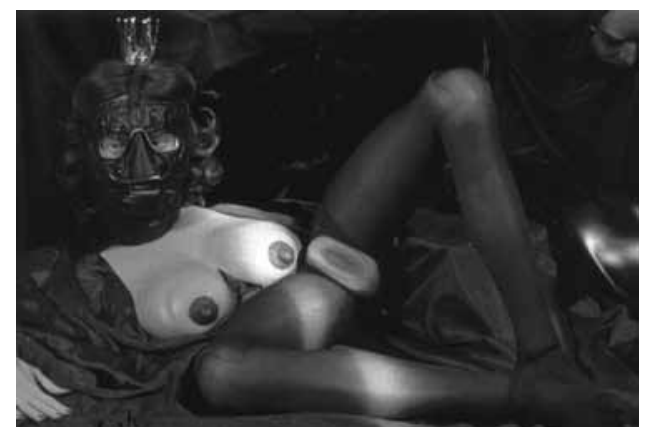

Figura 10

Untitled \# 264, 1992, Cindy Sherman

Com certeza estamos operando no domínio da arte e da ilusão - a sujeira do cólon é, ainda bem, sem cheiro e sem gosto - e, na vida cotidiana, essas fontes naturais, porém antropomórfi- 
cas, de significado foram excluídas, como demonstra a mini-história foucaultiana do desaparecimento do corpo. Mas é isso que ergue os suportes para a outra cena do ato de conhecer. Embora se trate de um espaço de ilusão, a foto de Sherman nos remete enfaticamente a um excesso sensorial e corpóreo, do qual o desgosto e/ ou o riso são uma marca.

Os desdobramentos dessas qualificações constituem a primeira tentativa, muito breve, de reconhecer o caráter absolutamente ilusório desses retratos, enquanto se prendem à profundidade de sua insistência sobre a natureza material, ilegítima e abusada. Quero sugerir que a insistência indutiva de Sherman toma o lugar, assim, da função das séries na arte modernista, isto é, o mecanismo de "entrar" num novo registro, que se prende revelador ou exemplar ${ }^{7}$. É muito tarde pra isso: o desastre já aconteceu, e nenhuma obra pode ser exemplar agora. A esse respeito, a indução de Sherman depende, para ser plausível, não só das séries de filmes de terror/ desastre/ sexo, mas também de tudo aquilo que conduz a eles, desde as Cenas de filme sem título, passando pelo "pink robe" e retratos de moda. Temos imagens inversas da mesma coisa: clichês externos, carnificina interior. Isso é a seqüência indutiva, mas apenas em virtude da seqüência é que nós, incluindo Sherman, podemos ver a indução envolvida aqui, o caráter de autenticidade da sua insistência. E essa insistência, estou afirmando, envolve algum tipo de encontro presente com a sensorialidade, embora ilusória, muito mais do que alguma argumentação sobre sensorialidade ou corporificação ou natureza ou espontaneidade. Tal argumentação seria filosófica e não arte. O fato de a linha entre as duas ter se tornado tão tênue é uma parte do desastre; mas apenas em virtude da insistência indutiva de Sherman é que isso pode ser visto, as perdas envolvidas podem ser calculadas e lamentadas. É quase certo, então, que a minha argumentação aqui mutila e limita demais o "argumento" dela.

Agora: existe algum outro modo público de unificar nossas crenças e emoções acerca da corporificação e enraizamento no mundo natural? Existe algum outro espaço compartilhado e social, em que as nossas crenças acerca dos nossos corpos poderiam ser transfiguradas tão radicalmente, a ponto de abrigar uma afirmação anticeticismo? O que sabemos, no sentido pleno do crer e sentir, sobre a nossa corporificação, que constitui melhor conhecimento, melhor reconhecimento do que aquele oferecido pelas imagens aterrorizantes de Sherman? Será que essas imagens podem ser observadas, cumulativamente, como nada mais do que uma indução transcendental das condições de significatividade, 


\section{assegurando, não a subordinação da natureza vida ao conhe- cimento, mas sua necessidade extrema?}

\section{NOTAS}

1. Snuff significa morte, assassinato, e é o título de um filme produzido nos anos 70, cuja propaganda afirmava que os atores que representavam personagens assassinados foram realmente mortos durante as filmagens. Termo que identifica um tipo de filme de horror dedicado a sexo e violência, em que a violência não é simulada.

2. Faz parte do dispositivo do contemporâneo os anacronismos do tempo.

3. House of Wax é uma expressão usada por Norman Bryson e que nomeia seu artigo. Cf. KRAUSS, 1993, p. 216-223.

4. Para Lacan o acesso do sujeito a uma ordem simbólica faz-se pela linguagem, ultrapassando a relação especular eu-outro da ordem do imaginário. O simbólico devolve as estruturas sociais reguladoras e constrói a identidade do sujeito assumida na face do imaginário. Considerando este quadro de forças, o sujeito existe assim fora de si mesmo num exterior ao seu imaginário. Se por um lado é efeito do discurso, por outro diz mais do que aquilo que tem consciência de dizer, porque existe um saber que ultrapassa aquilo que ele de si pode saber, $\mathrm{o}$ saber de uma ordem prévia, do simbólico, que faz a determinação significante. Mas também porque existe uma impossibilidade de que o todo se diga, existe um real que sobra. Este real resiste enquanto objeto parcial ou resto a apropriação do simbólico e torna-se causa do desejo que promove a sua emergência no interior do próprio simbólico. Do real só podemos falar, como já vimos, desse fluxo de fragmentos desordenados, passíveis de organização pela ideologia do cotidiano sob o nome de realidade. E então dos fragmentos das suas vidas e da emergência desses restos do real resistindo a realidade, não dominados pelo simbólico mas em conflito, que as "imagens de Cindy Sherman" falam. E aí que se joga a possibilidade de um discurso não submetido à condição de pertencimento de um arquivo da ideologia do cotidiano. A inclusão das singularidades num conjunto, que enquanto tal recusa uma identidade - a função simbólica que o arquivo está destinado a exercer -, torna-se a verdadeira ameaça para esta instância. Como dizia Giorgio Agamben: "a singularidade qualquer, que quer apropriar-se da própria pertença, do seu próprio ser na linguagem, e declina, por isso, toda a identidade e toda a condição de pertença, é o principal inimigo do Estado." Cf. AGAMBEN, 1993.

5. Aqui devo explicitar o pressuposto teórico subentendido. No começo dos anos 6o Jaques Lacan estava preocupado em definir o real em termos do trauma. Lacan define o traumático como um desencontro com o real. Enquanto perdido, o real não pode ser representado: ele só pode ser repetido. Repetir um evento traumático, nas ações, nos sonhos, nas imagens, de forma a integrá-lo à economia psíquica, que é uma ordem simbólica. Wiederholen, escreve Lacan em referência etimológica à idéia de repetição em Freud: repetição não é reprodução. Isso pode valer como epítome também do meu argumento: repetição em Sherman não é reprodução no sentido da representação (de um referente) ou simulação (de uma pura imagem, um significante despreendido). Antes, a reprodução serve para proteger do real, compreendido como traumático. Mas exatamente essa necessidade também aponta para o real, e nesse ponto o real rompe o anteparo proveniente da repetição.

6. A palavra cena é aliás muito ambígua, já que designa simultaneamente o espaço real, a área de interpretação, por extensão metonímica, o lugar imaginário onde se desenvolve a ação, e o fragmento de ação dramática que se desenrola em uma mesma cena (logo, um pedaço unitário da ação), portanto determinada unidade de duração. E sugerida aqui uma certa convergência das histórias da pintura com a do teatro e a do cinema.

Nas artes figurativas, por exemplo, a cena é, no fundo, a própria figura da representação do espaço, materializando bem, com a intuição do fora-do-campo, ao mesmo tempo que significa a não existência de representação do espaço sem uma representação de uma ação, sem diegese. Se o espaço é representado, é sempre como espaço de uma ação, ao menos virtual: como espaço de uma 
encenação. Isto é, o fora-de-campo na imagem fixa permanece para sempre não visto, sendo apenas imaginável; na imagem mutável, ao contrário, o fora-de-campo é sempre suscetível de ser desvelado, seja por um enquadramento mutável, seja pelo encadeamento com outra imagem. Cf. BARTHES, 1990.

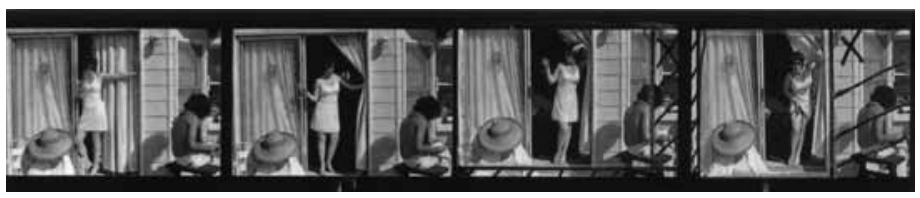

7. Modelos críticos em arte e teoria desde os anos 6o têm enfatizado um ceticismo com relação ao realismo e ilusionismo. Essa postura antiilusionista foi mantida por muitos artistas envolvidos com arte conceitual, crítica institucional, arte corporal, performance, site-specific, arte feminista e apropriação. O prazer problemático do cinema holywoodiano, por exemplo, ou o elogio ideológico da cultura de massa continuam sendo "coisas ruins" nesse modelo. De certa forma, a crítica ao ilusionismo continua a velha história da arte ocidental como a procura da representação perfeita, tal como foi contada de Plínio a Vasari e de John Riskin a Ernst Gombrich (que escreveu contra a arte abstrata); só que, aqui, o objetivo está invertido: abolir em vez de atingir essa representação. Mesmo assim, essa inversão carrega a estrutura da velha história - seus termos, valores e etc. Em paralelo a esse modelo, outra trajetória da arte estava comprometida com o realismo e/ou idealismo: algo da pop arte, super-realismo (também chamado de fotorrealismo), algo de arte de apropriação. Freqüentemente desbancada pela crítica de genealogia minimalista na literatura crítica (ou mesmo no mercado), essa genealogia pop é hoje novamente de interesse, pois ela complica as noções redutoras de realismo e ilusionismo e, de certa forma, igualmente ilumina o trabalho contemporâneo, que passa a ser renovado por essa categoria. Nossos dois modelos básicos de representação são praticamente incapazes de compreender o argumento dessa genealogia pop: de que imagens são ligadas a referentes, a temas iconográficos ou coisas reais do mundo, ou, alternativamente, de que tudo que uma imagem pode fazer é representar outras imagens, de que todas as formas de representação (incluindo o realismo) são códigos auto-referenciais. Tal argumento ilumina a compreensão das séries de Cindy Sherman.

Mediante a predominância da compulsão a repetir colocada em jogo por uma sociedade de produção e consumo, a insistência indutiva de Sherman nos diz que se você entra totalmente no jogo talvez possa expô-lo, isto é, você talvez revele o automatismo ou mesmo o autismo desse processo, por meio de seu próprio exemplo exagerado. Essa noção de repetição compulsiva reposiciona o papel da repetição nas séries modernistas. Não se quer que seja essencialmente o mesmo, mas exatamente o mesmo. Pois quanto mais se olha para exatamente a mesma coisa, tanto mais ela perde o seu significado. Aqui, a repetição é uma drenagem do significado. Cf. FOSTER, 1996

\title{
Referências Bibliográficas
}

\author{
AGAMBEN, Giorgio. A comunidade que vem. Lisboa: Editorial \\ Presença, 1993. \\ . Moyes sans fins - notes sur la politique. Paris: Édi- \\ tions Payot \& Rivages, 2002. \\ . O que é contemporâneo? E outros ensaios. São Paulo: \\ Argos, 2009. \\ BADIOU, Alain. Para uma nova teoria do sujeito. Rio de Janeiro: \\ Relume-Dumará, 1986. \\ BARTHES, Roland. O óbvio e o obtuso: ensaios críticos III. Rio
}


de Janeiro: Nova Fronteira, 1990.

BENJAMIN, W. Magia e técnica, arte e política: ensaios sobre literatura e história da cultura. $7^{\text {a }}$ ed. São Paulo: Brasiliense, 1994. V 1.

DELEUZE, Gilles. A imagem-movimento: cinema 1. São Paulo: Brasiliense, 1989.

.Mil Platôs: capitalismo e esquizofrenia. São Paulo: Ed. 34, 1996. V 3

DIDI-HUBERMAN, Images malgré tout. Paris: Éditions de Minuit, 2004

FOSTER, Hal. The return of the real: the avant-garde at the end of the century. London, Cambridge Mass.: MIT Press, 1996.

FOUCAULT, Michel. Historia da sexualidade 11 $^{\mathrm{a}}$ ed. Rio de Janeiro: Graal, 1993. V.1

KRAUSS, Rosalind. \& BRYSON, Norman. Cindy Sherman 19751993. New York: Rizzoli, 1993.

LACAN, Jacques. Seminário XI: Os quarto conceitos fundamentais da psicanálise. Rio de Janeiro: Zahar, 1979.

MITCHELL, W.J.T. The language of images. Chicago \& London: Chicago UP, 1974.

NIETSZCHE, Friedrich. Genealogia da moral: uma polêmica. São Paulo: Companhia das Letras, 1998.

THAMES \& HUDSON. Cindy Sherman-Retrospective. London: Thames \& Hudson,1997.

WITTGENSTEIN, Ludwig. Investigações Filosóficas. São Paulo: Ed. Nova Cultural Ltda, 1999.

ZIZEK, Slavoj. Bem-vindo ao deserto do real: cinco ensaios sobre o 11 de Setembro e datas relacionadas. São Paulo: Boitempo, Editorial, 2003.

Recebido em: 31/o8/10

Aceito em: 01/12/10

\section{DANUSA DEPES PORTAS}

danusadepes@yahoo.com.br

Doutoranda em Estudos de Literatura pela PUC-Rio e em Comunicação Cultura pela ECO/UFRJ. Mestre em Estudos de Literatura (PUC-RJ, 2005). Desenvolveu os projetos Imagem, Representação e Identidade Cultural na Literatura e nas Artes Brasileiras (CNPq, 1998 - 2001) e magens Contemporâneas (do Sublime) - um estudo em torno da experiência estética (FAPERJ MSC 10, 2003-2005). Integrante do grupo de pesquisa Tendências Atuais nos Estudos de Literatura (CNPq, 20032005) e do Imagem/Tempo (ECO, 2009). 